\title{
Experiences of Latino Community College Students in Overcoming Barriers to Persist
}

\author{
Tamara Wilkerson Dias \\ Morgan State University, United States
}

\begin{abstract}
While the number of Latino students taking advantage of higher education opportunities has steadily increased, the completion of degree programs does not mirror this increase (Radford, Berkner, Wheeless, \& Shepard, 2010). Prior research has focused on the barriers faced by Latino college students (Garza, 2011; Hernandez, 2002; Radovic, 2012). However, there is limited research on the journeys of Latino community college students and the strategies they use to achieve success. This study utilized Padilla's (1999) Model for Student Success to explore the barriers faced by Latino students at a community college and the strategies used by students to overcome them. Twelve students identified eleven barriers in the categories of personal, financial, coursework, learning, institutional, and student support. These students used experiential, institutional, knowledge about study skills, procedural, relational, and motivational knowledge to address their barriers. They also took strategic, pragmatic, persuasive, and supportive actions. Students emphasized the importance of building relationships with peers and staff and time management skills to balance their demanding work and school schedules. Based on the findings of this qualitative study, several recommendations were made including the expansion of peer tutoring programs, hiring additional translators to support students who are learning English, and the need for stronger relationships between community colleges and local high schools.
\end{abstract}

Keywords: community college, higher education, Latino, minority, persistence

Community colleges have served as the starting point to a postsecondary education for a variety of students, including racial and ethnic minorities, due to community college policies to open access. In 2014, there were 56 percent of Latino students pursuing an undergraduate degree through a community college, while there were 44 percent of Black students enrolled (Baum \& $\mathrm{Ma}, 2016)$. For White students enrolled in community colleges, there were only 39 percent (Baum \& Ma, 2016). Minority students are more likely than their White classmates to come from low socioeconomic backgrounds, be less academically prepared for college rigor, and less likely to attend full-time (Cohen \& Brawer, 2013).

Currently the biggest minority group in the United States at 17 percent, Latinos are also the fastest growing population (US Census Bureau, 2010). However, of the entire Latino population in the United States, 15 percent have obtained a bachelor's degree (National Center for Education Statistics [NCES], 2012). These numbers are 25 percent higher for White students 
and 8 percent higher for Black students, emphasizing the call for attention to degree completion for Latinos (NCES, 2012).

With the number of Latinos increasing, the education of this demographic impacts the ability to the nation to continue to thrive. The growing numbers of Latinos in America is mirrored in the increase of Latinos in community colleges. Scholars and administrators concerned with college retention and completion have begun to focus on minority populations, specifically Latino students (Abrego, 2008; Cebello, 2004; Martinez \& Fernandez, 2004; Velasquez, 1999). When students from Latino backgrounds attend colleges, they are more likely to attend a community college (Bailey, Jenkins \& Leinbach, 2005).

\section{LITERATURE REVIEW}

To understand how to support the retention of Latino students, it is important to have a background of their experiences as students. Crisp, Nora, and Taggert (2009) indicated that Latino students enter community college academically unprepared, with responsibility to support their families, financial concerns due to socioeconomic status, and outside responsibilities that require them to enroll part-time. Additionally, Latino students come from Spanish-speaking families and students desire to remain close throughout their community college journey (Smith, 2015). Each of these factors not only impacts how the students experience college, but their overall persistence and motivation along their academic journey.

\section{Part-Time Status}

Community colleges are flexible and offer courses in the morning, afternoon, and evening, allowing Latino students the opportunity to take courses around their own schedules. At two-year colleges, Latino students are more likely than any other group to enroll part-time due to working full-time jobs while taking courses (Handel, 2009), their part-time status is an essential component of their educational journey. However, according Adelman (2006), when students are not able to complete at least twenty credits in the first year of college, the likelihood that they will complete a degree decreases. For Latino students with already low degree completion rates (Fry, 2002), their part-time status further hinders their degree completion.

\section{Language}

Flores, Horn, and Crisp (2006) noted that community colleges enroll large numbers of Latino immigrant students. These Latino immigrant students come from countries that speak a different language than the primary language spoken in the United States (Barbosa, 2012). Razfar and Simon (2011) explained that many Latino community college students begin their postsecondary education as English Language Learners, still mastering the fundamental concepts of the English language. For this reason, students who are not fluent speakers of English struggle to progress through college courses in the United States (Cook, Perusse, \& Rojas, 2012; Razfar $\&$ Simon, 2011). Additionally, they face obstacles as they try to make sense of a new environment after high school and continue learning the English language. Many of the same Latino students who were in remedial English courses in high school continue to need remedial reading or writing courses in college (Nora \& Crisp, 2012).

\section{Family Values}


Culturally, Latino students bring important family values to their community college experiences, and are raised to value family interdependence (Ibarra, 2001). The location of community colleges, conveniently close to home, allows Latino students the opportunity to maintain the relationship with their families (Salias-Reyes \& Nora, 2012). Additionally, Smith (2015) found that Latino students feel responsible for providing for their families, and with this responsibility and family support, they are more likely to want to complete a degree program. When families of Latino community college students are unable to understand the commitment and persistence required to complete an academic program, this lack of understanding can lead students to drop out (Brandes, 2013; Martinez \& Fernandez, 2004).

\section{Socioeconomic Background}

Latino community college students are also more likely than their White classmates to come from low socioeconomic backgrounds. Baum and Flores (2011) noted that Latino students' experience is heavily impacted by their socioeconomic status. Research indicates that it is more difficult for Latino students to persist to degree completion when they come from low socioeconomic backgrounds (Fry, 2007). Because community colleges offer lower tuition rates than four-year institutions, these schools have higher numbers of Latino students from low socioeconomic backgrounds (Fry, 2007). Their ability to be successful while enrolled is influenced by their socioeconomic background prior to entering, and throughout their journey while attending (Santiago \& Galdeonado, 2014).

\section{Academic Readiness}

The academic readiness of Latino students is important, as Latino college students are more likely to have lower SAT scores and lower GPAs than their White counterparts (Crisp, Nora, \& Taggert, 2009), and enroll in community colleges because of this. Generally, students who enter college with these factors must enroll in developmental coursework, which do not count towards degree completion. Bustillos (2007) noted that because large numbers of Latino students are not enrolling in college preparatory courses, they are arriving at college unprepared for the academic demands of coursework. It is not surprising that students who are academically prepared are more motivated and have a stronger desire to persist to degree completion, while those who are not prepared struggle and are more likely to dropout (Izrarry \& Raible, 2011).

\section{Diverse Campus Climate}

Hurtado and Ponjuan (2005) explained that schools can have large numbers of Latino students but still not reflect diversity in their practices and institutional methods. Schools can also admit minority students, but not hire minority faculty and staff members (Hurtado \& Ponjuan, 2005). The lack of diversity impacts the environment, as students see the diversity on campus, but feel that diversity is not applicable to important decisions and norms which impact their education. While the student perception of diversity can vary from campus to campus, in environments where diversity is valued and reflected in practices and values, Latino students have had more positive experiences and felt included in their campus community (Lockette, 2007). 


\section{Institutional Supports for Student Retention}

Because community colleges recognize the importance of retaining Latino students, several practices have been implemented nationwide to encourage student success. Strategies such as mentoring and tutoring services, multiple placement measures, first-year orientation, and success courses all increase the likelihood of retaining Latino students. Each of these strategies aims to meet the unique needs of minority students who attend two-year schools.

\section{Mentoring Services}

Mentoring in college can help provide students with information on a more personal basis and allow them to form more substantial relationships. For Latino community college students, mentoring has been found to increase self-efficacy and confidence towards achieving academic goals (DeFreitas \& Bravo, 2012). Furthermore, Tovar (2014) discovered that mentoring increased academic persistence for Latino students, and the personal connections increased their engagement with their campus environment. For Latino students who are normally first-generation students, a mentor to keep them on track towards program completion is impactful (Strayhorn, 2010).

\section{Multiple Measures of Placement}

Duffy, Schott, Beaver, and Park (2014) explained that one of the key factors for creating multiple measures of placement into courses was due to the disproportionately higher number of African-Americans and Latinos enrolled in developmental coursework. Burdman (2014) noted that Latino students enrolled in developmental courses are required to take four or five such courses before progressing onto courses for college credit. Due to the lack of consistency in placement exams and entrance processes at colleges, Latino students benefit from multiple measures of placement for coursework (Burdman, 2014). Ngo and Kwon (2014) found that multiple measures of placement, such as high-school level coursework and high school achievements, do increase progress to higher-level courses, specifically for Latino students.

\section{First-Year Orientation}

For Latino students, orientation is essential in getting them acquainted with college faculty and staff and introducing them to the higher education environment (Colon, 2009). Colon (2009) researched orientation programs for Latino students and found that they were impactful in explaining the financial aid process, increasing overall confidence about attending college, and introducing the various academic offerings which are available for students. The research also indicated that 97 percent of the Latino students in attendance better understood the academic requirements after attending orientation (Colon, 2009). Ultimately, first-year orientation is an integral opportunity for Latino students, as it serves as their first step to being acquainted with their new postsecondary environment (Fuller, 2014).

\section{Success Courses}

Another tool implemented by administrators to enhance community college student achievement is the success course. The course helps students build necessary skills that they need 
in classes, such as time management and best practices for studying (Cho \& Karp, 2013). Although courses differ by institution, each course allows students to receive enhanced support in their first year. Some schools also require students to create an academic plan in which they detail their goals and the courses that are needed. According to Cho and Karp (2013), students who enroll in success courses felt they were focused going into the year and learned more about transitioning into a college environment from high school. Research has shown that students who participate in the short-term or semester-long courses feel more supported by their institution and are more likely to complete successfully developmental coursework.

\section{RESEARCH METHOD}

The study was conducted at a Mid-Atlantic community college with over 13,000 students. The pseudonym Mountain Peak Community College (MPCC) was given to ensure confidentiality of the school. The study consisted of personal interviews with students enrolled in at least six credit hours of coursework at a community college. I interviewed 12 Latino/a students ranging in age from twenty-one to twenty-four. Each participant also had to have completed at least two semesters of consecutive coursework at the college. A pseudonym was given to each participant to ensure confidentiality.

Once the interviews were completed, the researcher read through each of the interview transcripts line-by-line and conducted a two-step process for coding to search for themes and patterns. In the first step, the researcher focused on reading through each interview, while listening to the audio recordings. At this time, the researcher confirmed the accuracy of the data. During the second step, the researcher read through each transcribed interview again and assigned codes to do the interview data, while looking for patterns and themes.

\section{Participants}

Purposeful sampling was used to select each of the students who participated in the interviews. This method does not require a specific quantity of participants, but rather participants who can best enhance the research. Utilizing purposeful sampling allowed the researcher to identify participants who could best provide valuable and substantial answers to the research questions.

All participants self-identified as Latino and had to have completed at least two semesters of coursework at MPCC. The students wanted to share their experiences at MPCC and participated in the interview process voluntarily. The outcomes presented in this study are not generalizable, but they do offer a glance into the lived experiences of a small group of Latino community college students. The findings detail their unique, yet parallel, experiences as students.

\section{RESULTS}

The purpose of this qualitative study was to explore barriers faced by Latino students and the strategies used to overcome them. The research questions for this study were:

1. What are the barriers that Latino community college students at MPCC overcome to persist beyond their first year? 
2. What is the knowledge that Latino community college students need to overcome the barriers they faced?

3. What are the actions that Latino community college students had to take to overcome the barriers they faced?

This study focused on the experiences of Latino students at Mountain Peak Community College (MPCC), a community college located in the Mid-Atlantic. A pseudonym is utilized for the college to ensure anonymity.

\section{Research Question One}

The first research question for this study was: "What are the barriers that Latino community college students at MPCC overcome to persist beyond their first year?" The categories for barriers were personal, financial, coursework, learning, institutional, and student support. Participants dealt with an equal number of barriers in each category, except for institutional. Institutional barriers were the least prevalent for students in this study.

\section{Personal Barriers}

Personal barriers are identified as barriers as those directly related to a student's "individual health, family, social life, and abilities" (Padilla \& Norton, 2009, p.141). Participants in this study identified two personal barriers in their journeys. The first barrier was their responsibility to their families, specifically to children. Participants who were parents noted the difficulties in parenting and being full-time students. Ana shared that she had to take a year off from courses and that "school was not that important, "cause I had to provide." Students found it difficult to juggle their family lives and their school requirements.

The second personal barrier identified by participants was their lack of transportation to get to and from school. Arriving late for class was not only unacceptable by professors, but also caused participants to miss important information. Participants said that "because school is so far away from where I live - it's just stressful sometimes not having my own car." The lack of transportation made arriving to school more difficult for students.

\section{Financial Barriers}

Financial barriers are identified as barriers as those directly related to a student's employment, expenses, or funding (Padilla \& Norton, 2009). Participants worked part-time jobs while enrolled at MPCC. Luis shared that he had to help with the rent and other expenses at home, while having to study and take classes at night. He did not feel comfortable attending college and not contributing to his household and having a part-time job was a priority. Participants had to balance studying and completing assignments with their various work schedules.

Participants were also shocked about the cost of books and other supplies required for classes upon enrolling at MPCC. Coming from a high school setting where most materials were provided for them by their schools, attending a college and having to pay for all supplies was a new concept. Several participants explained that they did not know about these expenses prior to enrolling and wished they were more prepared. 


\section{Coursework Barrier}

Coursework barriers solely focus on issues that relate to the classroom and instruction (Padilla \& Norton, 2009). There was one coursework barrier identified by students, which highlighted the difficulties faced with developmental courses. Ana shared that enrolling in developmental courses slowed her down and made her feel "stuck." She enrolled at MPCC thinking that she would be finished in two years, not realizing the role that developmental courses would play into her ideal timeline for graduation. Participants realized that after taking developmental coursework, it would take them longer to graduate. Participants did not want to take the courses but understood that they were necessary for them to succeed in higher-level coursework.

\section{Learning Barriers}

Learning barriers are those that relate to academic readiness and skills needed once enrolled in courses (Padilla \& Norton, 2009). Participants noted their own experiences as native speakers of Spanish and/or coming from families where they were the first generation learning Spanish, made their academic journey more difficult. Rodrigo talked about his own experience when trying to speak English to his parents at home:

It's very hard to speak English to my parents because they didn't take classes like me. They try their best to learn it on their own and from friends, but I learned it in school. So, at home, I can't really talk to them in English. I definitely think it would be easier for me if everyone at home spoke English.

Students had to learn and communicate in a language that they had not yet fully mastered, making their classes more difficult. Participants, like Carmen, also noted that it took them longer to take notes and process information in class due to the language barrier.

\section{Institutional Barriers}

Institutional barriers are those that relate to the facilities and policies in place at the school. While participants identified one barrier in this category, it proved to be impactful. The location of the campus made their academic journey at MPCC more difficult. MPCC is in a suburban area and its main campus is where all participants took courses. Participants who lived in more rural areas traveled as far as forty minutes to and from classes if they had a car. Other participants spent over an hour getting to and from school if they utilized public transportation. When scheduling classes, students had to factor in the time it would take for them to commute to campus and to get home after classes. This was not an area they had considered prior to enrolling at MPCC.

\section{Student Support Barriers}

Student support barriers are the barriers as they relate to services provided by an institution. The first barrier in student support was the relationship between MPCC and area high schools. Many of the issues faced by students in the study were a result of not knowing about MPCC's policies and procedures prior to enrolling. Being that each of these participants were first-generation college students, they did not have the opportunity to ask their parents about what to expect upon enrolling at MPCC. 
The other barrier in this category was the lack of more translators at MPCC. Participants explained that they needed translators' assistance during quizzes and tests, but translators were not always available. Many translators were only available during the daytime hours and special requests had to be made for evening classes. Students shared their frustration in not having translators readily available when needed.

\section{Research Question Two}

The second research question for this study was: "What is the knowledge that Latino community college students need in order to overcome the barriers they face? According to Padilla (1999), heuristic knowledge is the knowledge gained by students through their experiences. They may or may not gain this knowledge in a formal classroom and it can be explained as a trial-by-error approach to learning. Participants shared about heuristic knowledge in the following categories: experiential, institutional, knowledge about study skills, procedural, relational, and motivational.

\section{Experiential Knowledge}

Experiential knowledge is the knowledge that relates to students' understanding of situations and their ability to draw from conclusions of their experiences. There were two areas of experiential knowledge that students identified. First, students realized that they could reach out to their professors to help. However, this knowledge was only gained after not asking for assistance at first and struggling through classes. Laura shared that at times she was afraid to ask for help, so she chose not to say anything. After realizing that her professors were available to help before and after class, she felt more comfortable asking for help.

The second area highlighted students' understanding of the tutoring services that were available to them. MPCC offers peer tutoring and tutoring from faculty to students. However, many participants did not know they had these options until they had unsatisfactory results on a test or quiz. Students were then able to draw on that experience and learn about the resources available.

\section{Knowledge about Study and Skills}

Knowledge about study skills is the knowledge that relates to students' study habits and skills that support their academic success. Participants noted the important role of the MPCC Success Program and its role overcoming barriers. The program connects students with a success advisor who checks in with them throughout the semester to ensure that they are meeting satisfactory progress through courses. Participants shared that the Success Program answered many of the questions they had regarding coursework and academic deadlines.

Participants also highlighted the knowledge of strong communication skills to persist beyond barriers. They realized the need for communication skills in their first year, after not communicating with faculty and staff when they needed help. Once they realized they needed communication skills to reach out to faculty and staff, they could progress through difficulties such as course scheduling or tutoring assistance.

\section{Procedural Knowledge}

Procedural knowledge is the knowledge that students need to complete a specific task. In this knowledge area, students spoke about knowing where to go for help and how to ask for help. Participants noted the value of knowing where to go for help. Carmen stated that it seemed 
as though "MPCC has an office for everything", but it's important to know where to go for assistance. While Carmen's professor was helpful with her History course, he could not assist her with financial aid. Therefore, it was essential for her to know where to go to ask for help with financial aid and who could assist her with completing documentation.

It was also important for participants to know how to ask for help. Jorge shared that he spent hours in the wrong office, because he did not know how to ask for the help he needed with requesting a translator. Once he was in the right office, it took less than ten minutes to complete his request. His large problem was instantly reduced, once he knew how to ask for help.

\section{Relational/Comparative Knowledge}

Relational or comparative knowledge is the knowledge that students use to "recognize relationships between phenomena" (Padilla \& Norton, 2009, p.143). For students in this study, their relational knowledge focused on students realizing the relationship between their lack of information prior to attending college and its impact on their journey. Jorge shared: "It would have been really helpful to just know more about everything. There's so much they don't tell you and I think people expected me to know stuff when I got here." They shared that high schools having more information about the community college would have been helpful in navigating through the first year.

Students also noted that understanding how to compare costs when purchasing books and supplies was an important part of their academic journey. After speaking with her Success Program advisor, Olivia realized that she could rent her textbooks online instead of purchasing them directly from the MPCC. She shared, "My advisor really helped me. How was I supposed to know I didn't have to purchase them from school? Once I knew, I told all of my friends!" This comparative knowledge enabled her to overcome the financial barrier of cost as it pertained to a financial barrier.

\section{Motivational Knowledge}

Motivational knowledge is the knowledge that participants use to direct them to take action to overcome barriers. Participants in this study were not aware of how much they needed peer support until they were in a situation that would have been easier to navigate with the assistance of peers. Ana, who met other students through he role in student government, found her peer relationships to be integral in her academics. Ana shared, "We help each other get good grades and we all work hard. It's nice having a group where everyone wants to be successful." Once she realized how important her network of peers would be in her academic success, she was able to connect with them outside of the student organization setting.

Students also shared that once they realized that they enjoyed taking a diverse range of courses, it made their journey more enjoyable. One of the recurring aspects that all participants enjoyed about MPCC was the variety of courses they could take ranging from culinary arts to nursing. Mariana shared that she loved how she could "experiment with different classes" and try out courses offered by MPCC. It made her experience more enjoyable and made it easier to persist through difficult courses.

\section{Research Question Three}

The final research question for this study was: "What were the actions that Latino community college students had to take in order to overcome the barriers they face? The 
categories for actions were strategic, pragmatic, persuasive, and supportive. Participants took actions in each of these categories, with the pragmatic actions being the most common.

\section{Strategic Actions}

In this study, the strategic actions taken by participants were those that related to "planning or achieving" (Padilla \& Norton, 2009, p.143). Students in this study highlighted the need for strategic action as it pertained to scheduling and time management. Participants shared that working around their own schedule was one of the main reasons they chose to attend MPCC. Because Luis had to work and support his family, his only option was to attend MPCC and take classes around his work schedule. Participants expressed the need for scheduling classes around work schedules and family demands and felt that it was necessary to work around their own schedules to be successful as students.

Participants also shared about the role of scheduling time with professors. Realizing that their professors were open to meeting before or after classes, participants had to set aside time when they needed assistance with course material. Participants, like Esteban, did not always feel comfortable asking questions during normal class times. Therefore, they had to take action as it pertained to scheduling meetings during office hours that were convenient for the professors.

\section{Pragmatic Actions}

Pragmatic actions were the most common area of actions taken by students in this study. Actions in this category were those that aided students in "solving problems in a practical manner" (Padilla \& Norton, 2009, p.143). Because participants faced a variety of barriers, problem solving to overcome these barriers was common.

In terms of finances, students applied for financial aid. Participants stated that the financial aid process was confusing during their first year and they did not know about the documents that would be needed to apply. However, taking the step to apply for financial aid allowed them to overcome financial barriers, because they realized they did not have to fund school on their own. Students also shared that they purchased books from cheaper sites. Once they had the knowledge of where to go for the books, they were able to plan and purchase books that were used and priced at a lower cost.

Because several participants had a commute of thirty or forty minutes to MPCC and wanted to schedule time with professors for assistance, they realized that it was necessary to arrive earlier to campus. Participants, like Jorge, chose to come earlier on days on which he had a shorter work schedule. Jorge was worried about how he would manage his sixty-hour work week and classes, but he picked one day to come an hour earlier and receive tutoring. Participants noted the importance of being able to arrive early to class and how it made them feel more prepared. It also allowed them to ask any questions before other students arrived.

The final action taken by students was their decision to talk to a student advisor. Participants shared about how academic advisors, as well as those assigned by the Success Program, were helpful for the vast array of questions and concerns they had in their first year. Success Program advisor assisted students who were struggling and needed additional supports to progress through course work. Participants felt that their advisors were supportive and wanted to help them solve problems.

\section{Persuasive Actions}

For participants in this study, persuasive actions were taken the least. Actions in this category focused on what students did to cause others to take action or bring about change in 
someone else's attitude. Participants spoke about letting professors know when emergencies occurred that cause academic conflicts, in order to receive assignment extensions. When Ana had an emergency with her daughter that caused her to spend a day in the hospital, she was unable to complete an assignment. After talking with her professor, she received an extension and was able to finish the assignment once she and her daughter returned home. Once she realized the importance of asking for an extension during emergencies, she communicated more often when more time was needed for assignments.

\section{Supportive Actions}

Supportive actions highlighted the actions that students took to aid or foster inclusion within the school community. Participants talked to other students and made friends during their first year as students. Luis and Esteban were active in sports, and Ana shared that her involvement in student government allowed her to make friends who became an extension of her family.

Participants also shared about supporting other students. They explained how it was important to not only to lean on other students for support, but it was important to support others as well. Flor explained how she supported friends who needed tutoring in areas where she excelled. She was happy to spend more time with her friends, and it helped her become adjusted at MPCC. She also appreciated the mutual support and the ways that she could help them in their journey. Participants also shared how supporting other students was second-nature and that they all "looked out for each other" when a student encountered an obstacle or problem.

\section{DISCUSSION AND CONCLUSIONS}

Understanding the experiences of Latino students who successfully overcome barriers throughout their collegiate journey is vital for college leaders who wish to improve outcomes for these students. Consequently, this study provided several concrete implications, and they concentrated on the experiences of Latino students who were able to continue onto their second year. Because all the participants in this study were in their second year and successfully progressing towards graduation, this study offers implications for practice.

This study also indicated the importance of additional opportunities for financial supports for students, not just for academic-related costs. This study demonstrated the importance of colleges considering the non-academic financial obligations that students face, which impacts their academic experiences. The college should also consider alternate ways to support students with financial obstacles that could impact their studies, such as transportation costs, especially for students who travel over an hour to take classes at the college.

Due to the important role that relationships with peers and faculty played in the successes of participants in this study, it is essential that schools allow opportunities for these relationships to be cultivated. Because participants noted that it would have been helpful to have a mentor upon enrolling, one portion of the program could pair an incoming student with a second-year student at the college. The second component could pair a second-year student with a faculty mentor for additional support. With this model, the peer mentor is supported by the faculty mentor, so that he/she is better able to assist the incoming student.

Because students noted the lack of awareness of college information prior to entering, it is important for the institution to consider ways they can reach more high school students. The college should consider having a liaison who makes consistent visits to the local high schools and can serve as a source of information for students. Partnering with local community groups is 
also a way to reach more students prior to their enrollment. Through community group presentations, the college also has a chance of reaching the families of potential students.

This study also provided evidence that language is a consistent barrier for Latino students in community colleges. Having more staff members who are fluent in Spanish to communicate to the school's growing Spanish-speaking population of students can assist those who may need immediate translation services. The school should also consider having information sessions related to financial aid conducted completely in Spanish to connect with Spanish-speaking students and families. Schools should also consider integrating more bilingual resources for parent education to support families of Latino students.

While this study contributed to the understanding of the Latino student experience from the perspective of the students, there were several limitations to this study. By focusing on a specific demographic, there was a limited number of students who could participate in the study. The study was also limited to the community college setting and did not include other institutions of higher education. The study was also limited to a suburban environment. Additionally, those who volunteered to share their experiences were chosen. Therefore, this study did not incorporate the opinions and experiences of the students who decided not to participate. Future research

To increase the graduation rates of Latino students, colleges have begun to focus their efforts on retention of this population. This study shed light onto the multiple ways that Latino students have overcome barriers to persist and succeed in their community college experiences. It is important to consider the ways that community colleges can better support Latino students in their journeys and encourage their success.

\section{REFERENCES}

Abrego, L. (2008). Legitimacy, social identity, and the mobilization of law: The effects of Assembly Bill 540 on undocumented students in California. Law \& Social Inquiry, 33(3), 709-734.

Adelman, C. (2006). The toolbox revisited: Paths to degree completion from high school through college. Washington, DC: U.S. Department of Education

Bailey, T. R., Jenkins, D., \& Leinbach, D. T. (2005). What we know about community college low-income and minority student outcomes. New York, N.Y.: Community College Research Center, Columbia University

Barbosa, L.L. (2012). A study of college access and academic success among first generation Hispanic language minority students at the community college level (Doctoral dissertation. Retrieved from ProQuest Dissertations and Theses. (UMI No: 3520136)

Baum, S. \& Ma, J. (2016). Trends in community colleges: Enrollment, prices, student debt, and completion. College Board Research, 1-23. Retrieved from www.collegeboard.com/trends.

Brandes, D.R. (2013). Latino student success at an emerging Hispanic serving community college: Understanding the heuristics at work within the black box ( Doctoral dissertation). Retrieved from ProQuest Dissertations and Theses. (UMI No: 3587058)

Bustillos, L.T. (2007). Exploring faculty beliefs about remedial mathematics students: A collaborative inquiry approach (Doctoral dissertation). Retrieved from ProQuest Dissertations and Theses. ( UMI No: 3261848)

Cho, S., \& Karp, M. (2013). Student success courses in the community college: Early enrollment and educational outcomes. Community College Review, 41(1), 86-103. Retrieved from: http://journals.sagepub.com/doi/abs/10.1177/0091552112472227?journalCode=crwa.

Cohen, A., \& Brawer, F. (2008). The American community college (5th ed.). San Francisco: Jossey-Bass.

Cook, A., Pérusse, R., \& Rojas, E. D. (2012) Increasing academic achievement and college-going rates for Latina/o English language learners: A survey of school counselor interventions. Journal of Counselor Preparation \& Supervision, 4(2), 24-40. Retrieved from: 
https://repository.wcsu.edu/cgi/viewcontent.cgi?referer=https://www.google.com/\&httpsredir=1 \&article $=1008 \&$ context $=\mathrm{jcps}$.

Colon, C.N. (2009). Development of a Latino student and parent orientation program at the urban community college (Doctoral dissertation). Retrieved from ProQuest Dissertations and Theses. (UMI No: 3396636).

Crisp, G., Nora, A., \& Taggart, A. (2009). Student characteristics, pre-college, college, and environmental factors as predictors of majoring in and earning a STEM degree: An analysis students attending a Hispanic serving institution. American Educational Research Journal, 46(4), 924-942. Retrieved from http://journals.sagepub.com/doi/abs/10.3102/0002831209349460? journalCode $=$ aera.

DeFreitas, S. C., \& Bravo, A., Jr. (2012). The influence of involvement with Faculty and mentoring on the self-efficacy and academic achievement of African American and Latino college students. Journal of the Scholarship of Teaching \& Learning, 12(4), 1-11. Retrieved from: https://josotl.indiana.edu/article/view/2083.

Flores, S. M., Horn, C. L., \& Crisp, G. (2006). Community colleges, public policy, and Latino student opportunity. New Directions for Community Colleges, 2006(133), 71-80. Retrieved from: http://onlinelibrary.wiley.com/doi/10.1002/cc.229/abstract.

Fry, R. (2002). Latinos in higher education: Many enroll, too few graduate. Washington, DC: Pew Hispanic Center.

Fry, R. (2007). The changing racial and ethnic composition of U.S. public schools. Washington, DC: Pew Hispanic Center Report. Retrieved from http://pewhispanic.org/files/reports/79.pdf

Fuller, I. (2014). Redesigning the first-year orientation course: How a discipline-specific approach can deepen student engagement. Liberal Education, 100(3). Retrieved from: https://eric.ed.gov/?id=EJ1095207.

Handel, S.J. (2009). Transfer and the part-time student: Reflections on the gulf that separates community colleges and selective universities. New York: The College Board.

Hurtado, S., \& Ponjuan, L. (2005). Latino educational outcomes and the campus climate. Journal of Hispanic Higher Education, 4(3), 235-251. Retrieved from: http://journals.sagepub.com/doi/abs/10.1177/1538192705276548?journalCode=jhha.

Ibarra, R.A. (2001). Beyond Affirmative Action: Reframing the context of higher education. Madison, Wisconsin: The University of Wisconsin Press

Irizarry, J. G., \& Raible, J. (2011). Beginning with El Barrio: Learning from exemplary teachers of Latino students. Journal of Latinos and Education, 10(3), 186-203. Retrieved from: http://digitalcommons.unl.edu/cgi/viewcontent.cgi?article=1185\&context=teachlearnfacpub.

Lockette, T. (2007, February). Hispanic students perform better in colleges with larger Hispanic communities, UF study finds. University of Florida News, B3

Martinez, M., \& Fernandez, E. (2004). Latinos at community colleges. New Directions for Student Services, 105, 51-62. Retrieved from: http://onlinelibrary.wiley.com/doi/10.1002/ss.116/abstract.

National Center for Educational Statistics (2014). Higher education: Gaps in access and persistence study. Retrieved from: https://nces.ed.gov/pubs2012/2012046.pdf

Ngo, F. \& Kwon, W.W. (2014). Using multiple measures to make math placement decisions: Implications for access and success in community colleges. Research in Higher Education, 56(5), 442-470. Retrieved from: https://link.springer.com/article/10.1007/s11162-014-9352-9.

Nora, A. \& Crisp, G. (2012). Hispanic student participation and success in developmental education. San Antonio, TX: Hispanic Association of Colleges and Universities.

Padilla, R. V. (1999). College student retention: Focus on success. Journal of College Student Retention, 1(2), 131-145. Retrieved from: http://journals.sagepub.com/doi/abs/10.2190/6W96-528BN1KP-H17N?journalCode $=$ csra.

Padilla, R.V. \& Norton, G. (2009). Student success in a Hispanic serving university. In R.V. Padilla, (Ed.), Student success modeling: Elementary school to college, (pp. 158-178). Sterling, VA: Stylus. 
Razfar, A., \& Simon, J. (2011). Course-taking patterns of Latino ESL students: Mobility and mainstreaming in urban community colleges in the United States. TESOL Quarterly, 45(4), 595627. doi: $10.505 /$ tq. 2011.268060

Santiago, D.A. \& Galdeonado, E.C. (2014). Latino college completion: United states. Washington, D.C.: Excelencia in Education. Salias-Reyes, N.A.\& Nora, A. (2012). Lost among the data: A review of Latino first generation college students. Washington, DC: Hispanic Association of Colleges and Universities.

Smith, R.D. (2015). Why Latino American community college students drop out after one semester (Doctoral dissertation). Retrieved from ProQuest Dissertations and Theses.

Tovar, E. (2014). The role of faculty, counselors, and support programs on Latino/a community college students' success and intent to persist. Community College Review, 43(1), 46-71. Retrieved from: http://journals.sagepub.com/doi/abs/10.1177/0091552114553788.

United States Census Bureau (2010). 2010 Current Population Survey. Retrieved from: http://aspe.hhs.gov/health/reports/2010/CPSHealthIns2011/ib.shtmlhttp://aspe.h s.gov/health/reports/2010/CPSHealthIns2011/ib.shtml

Velásquez, P. (1999). The relationship between cultural development sense of belonging and persistence among Chicanos in higher ed: An exploratory study. Paper presented at the Annual Meeting of the Association for the Study of Higher Education, San Antonio, TX. Retrieved from http://catalogue.nla.gov.au/Record/5666008

TAMARA WILKERSON DIAS, EdD, is the Executive Director of African American Teaching Fellows, and a graduate of the Community College Leadership Doctoral Program at Morgan State University. Her major research interests lie in student success and retention, students of color in higher education, and community colleges. Email: tamarawdias@gmail.com 